\title{
Вплив метіоніну
}

на морсологічні зміни

щитоподібної залози щурів

\section{Р.В. Янко}

Інститут фізіології ім. О.О. Богомольця НАН України

Резюме. Мета - дослідити вплив сірковмісної амінокислоти метіоніну на морфологічні зміни щитоподібної залози дорослих щурів. Матеріал і методи. Дослідження проведено на 24 щурах-самцях лінії Wistar віком 15 місяців. Дослідні щури на доповнення до стандартного раціону щодня перорально отримували метіонін у дозі 250 мг/кг маси тіла. Тривалість експерименту становила 21 добу. Із тканини щитоподібної залози виготовляли гістологічні препарати за стандартною методикою. Морфометрію залози здійснювали на цифрових зображеннях за допомогою комп'ютерної програми Image J. Результати. Виявлено, що 21-добове введення метіоніну дорослим щурам приводило до збільшення відносної площі паренхіми залози, зменшення розмірів фолікулів і колоїду, зростання фолікулярно-колоїдного індексу та зниження індексу накопичення колоїду, збільшення чисельності резорбційних вакуолей у колоїді фолікулів, зростання кількості інтерфолікулярних острівців, зменшення відносної площі строми в залозі. Висновки. Введення метіоніну (у дозі 250 мг/кг) приводить до появи морфологічних ознак зростання синтетичної активності щитоподібної залози. Це може мати практичний інтерес у плані використання метіоніну для підвищення функції залози.

Ключові слова: метіонін, щитоподібна залоза.

Щитоподібна залоза (ЩЗ) регулює всі види обміну речовин, роботу серцево-судинної та нервової систем, фізичний і розумовий розвиток. Якщо в її роботі відбувається збій, це неодмінно позначається на самопочутті та стані організму. За статистикою Всесвітньої організації охорони здоров’я, серед ендокринних захворювань патологія ЩЗ посідає перше місце [1]. В Україні

\footnotetext{
* Адреса для листування (Correspondence): Інститут фізіології ім. О.О. Богомольця НАН України, вул. Богомольця, 4, м. Київ, 01024. Україна.

E-mail: biolag@ukr.net

() Р.B. Янко
}

на частку захворювань Щ3 припадає 44,8\% від усіх ендокринних захворювань. Це зумовлює актуальність пошуку методів, шляхів можливої корекції стану ЩЗ, підвищення (за потреби) її функціональної активності. Одним із методів нормалізації фізіологічних функцій ЩЗ може бути застосування сірковмісних сполук, насамперед метіоніну. Відомо, що сірка є регулятором гормонів ЩЗ, вона контролює перетворення трийодтироніну на тироксин. Коли в організмі достатньо сірки, ЩЗ меншою мірою схильна до 
зниженого або підвищеного вироблення своїх гормонів [2, 3].

Метіонін - незамінна амінокислота, що входить до складу ферментів і майже всіх тканин. Метіонін добре впливає на стан нирок, знижує токсичність багатьох отруйних речовин і сприяє відновленню функцій печінки, є джерелом неорганічної сірки в організмі, сприяє прискоренню росту. Він є складовою багатьох білків і пептидів, бере участь у синтезі адреналіну, креатину, колагену, нуклеїнових кислот та інших біологічно важливих сполук. Метіонін відіграє роль в активізації дії гормонів, ферментів, вітаміну $\mathrm{B}_{12}$ тощо. Надходить в організм разом з їжею або лікарськими препаратами. Метаболізм метіоніну залежить від різних регуляторних систем, у тому числі й від дії гормонів [4-9].

Проте, незважаючи на добре вивчену роль метіоніну в організмі, даних щодо його впливу на функціональну активність і морфологічні зміни в ЩЗ бракує, а наявні результати мають неоднозначний характер $[10,11]$. Це може бути пов'язано 3 використанням в експериментах тварин різних видів і віку, відмінностями в дозуванні метіоніну, сезонністю та тривалістю проведення експериментів тощо. Більшість наявних праць присвячено дослідженню впливу дефіциту метіоніну в їжі на синтетичну активність Щ3 $[11,12]$. Яким же буде ефект після додаткового введення метіоніну до стандартного раціону, належало з'ясувати нам.

Мета роботи - дослідити вплив метіоніну на морфологічні зміни щитоподібної залози дорослих щурів.

\section{Матеріал і методи}

Дослідження проведено в осінній період року на 24 щурах-самцях лінії Wistar віком 15 місяців. Тварини як контрольної, так і дослідної груп перебували в уніфікованих умовах зі стандартним раціоном. Щури були розділені на 2 групи (по 12 тварин у кожній): I - контрольну та II дослідну, тварини якої на доповнення до стандартного раціону щодня перорально протягом 21 доби отримували метіонін у дозі 250 мг/кг маси тіла. Така доза метіоніну може розглядатися як профілактична, адже не призводить до суттєвого підвищення його вмісту в організмі та виникнення гомоцистеїнеміі, але є достатньою для корекції можливого дефіциту амінокислоти в ор- ганізмі до значень фізіологічної норми. Щурів декапітували під легким ефірним наркозом. Роботу зі щурами проводили відповідно до принципів Гельсінської декларації 1975 року та її перегляду 1983 року, а також згідно з «Правилами виконання робіт із використанням експериментальних тварин», затвердженими МОЗ України.

Із тканини ЩЗ виготовляли гістологічні препарати за стандартною методикою: фіксували в рідині Буена, зневоднювали в спиртах зростаючої концентрації (від 70 до 96 $)$ ) та діоксані. Отримані зразки заливали в парафін. Парафінові зрізи завтовшки 5-6 мкм виготовляли на санному мікротомі, забарвлювали гематоксиліном Бемера та еозином. Для візуалізації елементів сполучної тканини застосовували методи двота трикольорового забарвлення за Ван-Гізоном i Массоном [13]. Із використанням цифрової камери мікропрепарати фотографували на мікроскопі Nicon (Японія). Морфометрію здійснювали за допомогою комп'ютерної програми Image J [14].

На гістологічних зрізах ЩЗ вимірювали площу поперечного перетину фолікулів, колоїду та фолікулярного епітелію; зовнішній і внутрішній діаметри фолікулів; висоту фолікулярного епітелію. Підраховували середню кількість тиреоцитів у фолікулах. Визначали фолікулярно-колоїдний індекс та індекс накопичення колоїду. Із використанням методу накладання точкових морфометричних сіток вираховували відносну площу сполучної тканини, паренхіми залози та визначали стромально-паренхіматозний індекс - відношення відносної площі строми до відносної площі паренхіми залози. Вимірювали ширину прошарків міжчасткової, міжчасточкової та міжфолікулярної сполучної тканини [15, 16].

Статистичну обробку здійснювали методами варіаційної статистики за допомогою комп'ютерної програми Statistica 6.0. Нормальність розподілу цифрових масивів перевіряли за критерієм Пірсона. За нормального розподілу для оцінки вірогідності різниці між показниками використовували t-критерій Стьюдента. Розбіжності вважали вірогідними за р<0,05.

\section{Результати та їх обговорення}

Щ3 щурів після впливу метіоніну мала збережену структуру, з чітким розподілом на центральну та периферичну зони. Фолікули в ЩЗ 
мали овальну та видовжену форму, різну величину. Фолікули дрібного та середнього розміру локалізувалися в центральній частині залози, великого розміру - по периферії. У ЩЗ інтактних тварин колоїд у фолікулах мав рівномірне рожеве забарвлення, помірну або щільну консистенцію з резорбційними вакуолями. Колоїд фолікулів дослідних тварин був помірної щільності, часто пінистим із численними резорбованими вакуолями, що свідчить про вивільнення гормонів (рис.).

У тварин, які отримували метіонін, спостерігали вірогідне зростання відносної площі паренхіми Щ3 на 13\% порівняно з контролем. Площа поперечного перетину фолікулів і колоїду в ЩЗ дослідних щурів вірогідно зменшилась на 21\% і 40\% відповідно, тоді як площа фолікулярного епітелію залишалася без змін. Зовнішній і внутрішній діаметри фолікулів у ЩЗ щурів після введення метіоніну також зменшились на $17 \%$ і 28\% ( $<0,05)$ відповідно порівняно з контрольними показниками (табл. 1). Зниження розмірів фолікулів і колоїду може вказувати на зростання активності ЩЗ, пов'язану насамперед із вивільненням гормонів у кровоносне русло. У малоактивному стані Щ3 становлять фолікули переважно великого розміру за рахунок депонування гормонів у середині фолікула, збільшення об’єму колоїду [15].

Тиреоцити дослідних щурів мали кубічну та призматичну форму. Висота їх і середня кількість у фолікулі не мали вірогідних відхилень від контрольних показників.

Фолікулярно-колоїдний індекс (відношення площі поперечного перетину фолікулярного епітелію до площі колоїду) у дослідних щурів був вірогідно більшим на $67 \%$ за контрольний показник, тоді як індекс накопичення колоїду (відношення внутрішнього діаметра фолікула до подвійної висоти фолікулярного епітелію), навпаки, був меншим на $31 \%(\mathrm{p}<0,05)$. Зростання фолікулярно-колоїдного індексу та зниження індексу накопичення колоїду свідчить про посилення секреції тиреоїдних гормонів у кровоносне русло [17].

У дослідних щурів спостерігали тенденцію до збільшення кількості інтерфолікулярних острівців, що можна вважати ознакою активації процесів регенерації ЩЗ. Інтерфолікулярні острівці містять малодиференційовані клітини, які можуть бути джерелом для формування нових фолікулів [15].

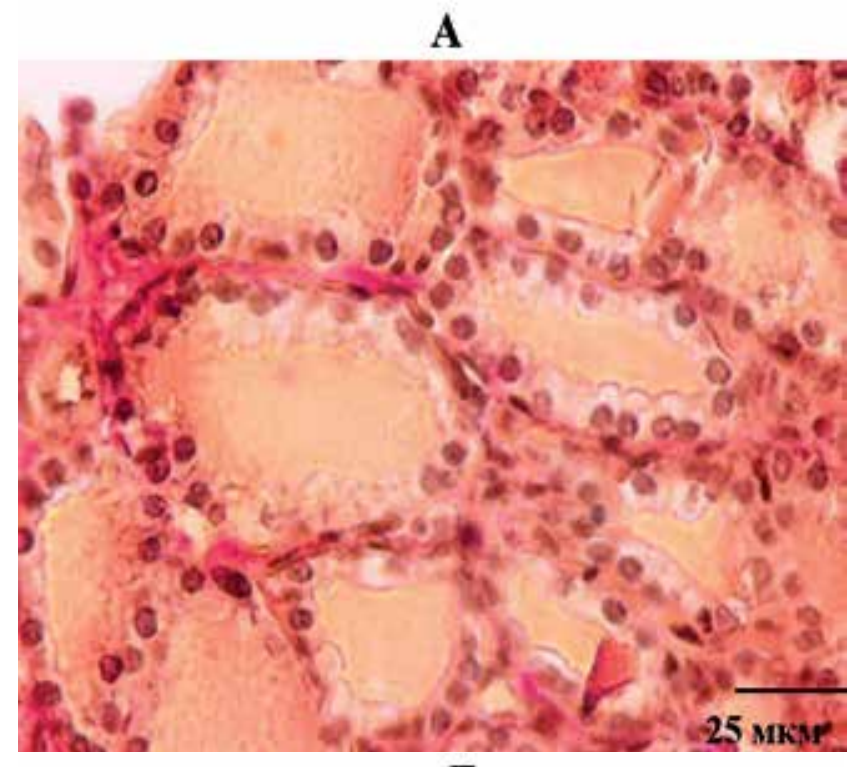

\section{Б}

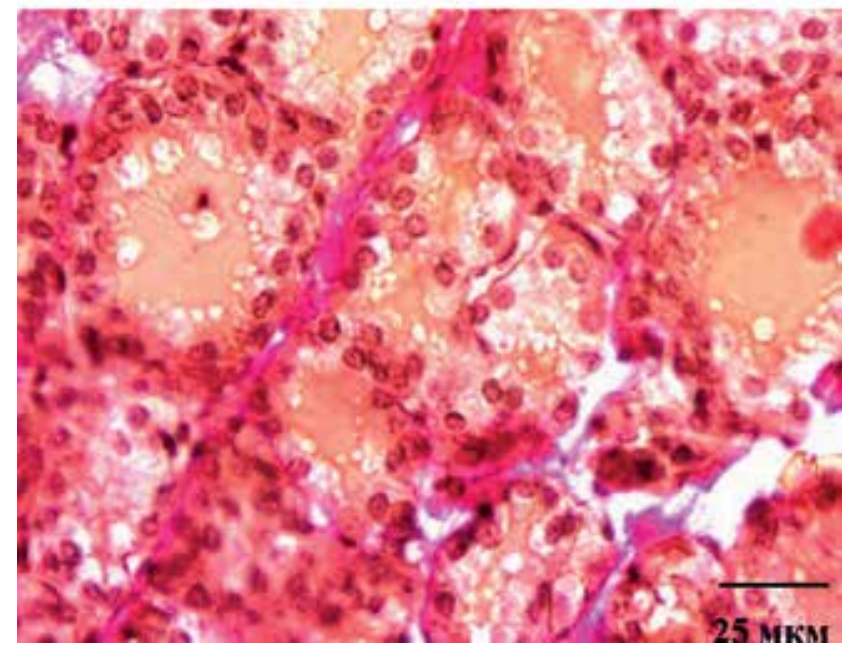

Рис. Мікрофотографія зрізу щитоподібної залози контрольної тварини (А) та щура, який отримував метіонін (Б): забарвлення за методом Ван-Гізон, х800.

таблиця 1. Морфометричні показники стану щитоподібної залози ( $\mathrm{M} \pm \mathrm{m}, \mathrm{n}=12)$

\begin{tabular}{lll}
\hline Показник & Контроль & Дослід \\
\hline Відносна площа паренхіми, \% & $66,9 \pm 2,44$ & $75,7 \pm 0,88^{*}$ \\
$\begin{array}{l}\text { Площа, мкм² } \\
\text { фолікула }\end{array}$ & $3706 \pm 136$ & $2922 \pm 108^{*}$ \\
колоїду & $1965 \pm 103$ & $1175 \pm 37^{*}$ \\
фолікулярного епітелію & $1741 \pm 90$ & $1747 \pm 61$ \\
Діаметр фолікула, мкм & & \\
зовнішній & $66,7 \pm 2,49$ & $55,3 \pm 2,17^{*}$ \\
внутрішній & $44,2 \pm 2,56$ & $31,8 \pm 2,76^{*}$ \\
Висота тиреоцитів, мкм & $11,3 \pm 0,45$ & $11,8 \pm 0,44$ \\
Кількість тиреоцитів у фолікулі, n & $24,5 \pm 0,98$ & $22,4 \pm 0,69$ \\
Фолікулярно-колоїдний індекс, од. & $0,89 \pm 0,04$ & $1,49 \pm 0,11^{*}$ \\
Індекс накопичення колоїду, од. & $1,96 \pm 0,17$ & $1,35 \pm 0,18^{*}$ \\
\hline
\end{tabular}

Примітка: * - вірогідна різниця з контролем $(p<0,05)$. 
До складу сполучнотканинного остову залози входять капсула та строма. В останній розрізняють міжчасткову, міжчасточкову, міжфолікулярну та паравазальну сполучну тканину (СТ). Міжчасткова СТ оточує частку залози ззовні. Міжчасточкова СТ розділяє паренхіму ЩЗ на часточки. До іiї складу входять тонкі пучки колагенових волокон, які переплітаються в різних напрямках. Міжфолікулярна СТ складається $з$ ретикулярних і колагенових волокон, які вплітаються у фолікулярні оболонки, зв’язуючи фолікули між собою. Паравазальна СТ оточує судини залози. Її представлено переважно еластиновими, меншою мірою - колагеновими волокнами [17].

Виявлено, що в тварин після введення метіоніну відносна площа строми в ЩЗ була меншою на $27 \%(\mathrm{p}<0,05)$ порівняно з контролем. Це привело до вірогідного зниження стромально-паренхіматозного індексу на 35\%. Також у Щ3 дослідних щурів спостерігали вірогідне зниження ширини прошарків міжчасткової, міжчасточкової та міжфолікулярної СТ на 21\%, 33\% і 25\% відповідно порівняно з контрольними показниками (табл. 2). Зміна цих морфометричних показників свідчить про відносне зменшення маси СТ у залозі, що, у свою чергу, поліпшує міжфолікулярний обмін речовин і проникнення гормонів крізь гістогематичний бар’єр у кров.

Наразі серед нечисленних літературних даних не існує однозначного висновку щодо впливу метіоніну на активність ЩЗ. Це, найімовірніше, пояснюється різними умовами проведення експериментів. Одні автори досліджували рівні тиреоїдних гормонів у плазмі курчат, які отримували їжу з нестачею метіоніну. Так, контрольні курчата отримували раціон із 0,5\% вмістом метіоніну, а птахи дослідних груп -метіонін-дефіцитні раціони з 0,4\%, 0,3\% і 0,2\% вмістом амінокислоти. Виявлено, що концентрація трийодтироніну в сироватці крові була вищою в усіх дослідних курчат (найбільшою в групі з 0,3\% вмістом метіоніну) порівняно 3 контролем. А концентрація тироксину в сироватці крові, навпаки, була нижчою в усіх дослідних групах (найменшою в групі з 0,2\% вмістом метіоніну). Тобто, дефіцит метіоніну по-різному змінює рівні тиреоїдних гормонів у сироватці крові [11]. Показано, що обмежене споживання метіоніну впливає на генерацію гормонів ЩЗ, які пов'язані з біогенезом мітохондрій [10]. В іншій праці ви-
Таблиця 2. Морфометричні показники стану сполучної тканини в щитоподібній залозі ( $\mathrm{M} \pm \mathrm{m}, \mathrm{n}=12)$

\begin{tabular}{lll}
\hline Показник & Контроль & Дослід \\
\hline Відносна площа строми, \% & $33,1 \pm 1,95$ & $24,3 \pm 0,88^{*}$ \\
Стромально-паренхіматозний індекс, од. & $0,49 \pm 0,09$ & $0,32 \pm 0,05^{*}$ \\
Ширина прошарків сполучної & & \\
тканини, мкм & & \\
міжчасткова & $27,5 \pm 2,35$ & $21,8 \pm 1,01^{*}$ \\
міжчасточкова & $12,9 \pm 0,74$ & $8,6 \pm 0,46^{*}$ \\
міжфолікулярна & $1,69 \pm 0,07$ & $1,26 \pm 0,06^{*}$
\end{tabular}

Примітка: * - вірогідна різниця з контролем $(p<0,05)$.

явлено, що додавання метіоніну до їжі посилює дію тиреоїдних гормонів [18]. Усі ці результати свідчать про різнобічну роль метіоніну (залежно від концентрації його введення) на активність ЩЗ, що потребує подальших досліджень.

\section{Висновки}

1. 21-добове введення метіоніну (у дозі 250 мг/ кг) дорослим щурам привело до появи морфометричних ознак підвищення функціональної активності щитоподібної залози - вірогідного збільшення відносної площі паренхіми залози, зменшення розмірів фолікулів і колоїду, зростання фолікулярно-колоїдного індексу та зниження індексу накопичення колоїду, появи численних резорбованих вакуолей у колоїді фолікулів, збільшення чисельності інтерфолікулярних острівців, зменшення відносної площі строми в залозі.

2. Ці дані можуть мати не лише теоретичне значення, але й становити певний практичний інтерес у плані використання метіоніну для підвищення функції щитоподібної залози.

\section{Список використаної літератури}

1. Vanderpump MP. The epidemiology of thyroid disease. Br Med Bull. 2011 Sept;99:39-51. doi: 10.1093/bmb/ldr030.

2. Stefl J. Effect of sulfur on thyroid function. Cesk Fysiol. 1959 Apr;8(3):251.

3. Avci G, Birdane YO, Özdemir M, Kukukkurt İ, Eryavuz A. Effects of sulfur supplementation on thyroid hormones in Angora Goats fed with a high nitrate diet. Kocatepe Veterinary Journal. 2018; 11(3):203-7. doi:10.30607/kvj.397352.

4. Chandler TL, White HM. Choline and methionine differentially alter methyl carbon metabolism in bovine neonatal hepatocytes. PLoS One. 2017;12(2):e0171080.

5. Taniguchi K, Shoji H, Solomonow M, Yazdani M, Nakamoto T Effects of excess methionine on collagen metabolism: a study on newborn rat skin. Biochem Med Metab Biol. 1987;37(1):125-31.

6. Toohey JI. Vitamin B12 and methionine synthesis: a critical review. Is nature's most beautiful cofactor misunderstood? Biofactors. 2006;26(1):45-57.

7. Vuyyuri SB, Hamstra DA, Khanna D, Hamilton CA, Markwart SM, Campbell KC, et al. Evaluation of D-methionine as a novel oral 
radiation protector for prevention of mucositis. Clin Cancer Res. 2008;14(7):2161-70. doi: 10.1158/1078-0432.CCR-07-1954.

8. Wan J, Ding X, Wang J, Bai S, Peng H, Luo Y, et al. Dietary methionine source and level affect hepatic sulfur amino acid metabolism of broiler breeder hens. Anim Sci J. 2017;88(12):201624. doi: 10.1111 /asj.12882

9. Taniguchi M, Nagao K, Inoue K, Imaizumi K. Cholesterol lowering effect of sulfur-containing amino acids added to a soybean protein diet in rats. J Nutr Sci Vitaminol (Tokyo). 2008;54(6):448-53.

10. Zhang J, Wang Y, Guo H, Shi Y, Le G. The effects of methionine restriction on thyroid hormones and mitochondrial changes in skeletal muscle. The Faseb Journal/Published Online. 2017; Abstract Number:794.15.

11. Carew LB, McMurtry JP, Alster FA. Effects of methionine deficiencies on plasma levels of thyroid hormones, insulin-like growth factors-I and -II, liver and body weights, and feed intake in growing chickens. Poult Sci. 2003;82(12):1932-8.

12. Yang Y, Zhang J, Wu G, Sun J, Wang Y, Guo H, et al. Dietary methionine restriction regulated energy and protein homeostasis by improving thyroid function in high fat diet mice. Food Funct. 2018 Jul;9(7):3718-31. doi: 10.1039/c8fo00685g

13. Данилов РК. Руководство по гистологии. Том II. СанктПетербург. СпецЛит. 2011 (Danilov RK. Guide to histology. Volume II. St. Petersburg. SpecLith. 2011).

14. Никоненко АГ. Введение в количественную гистологию. Киев: Книга-Плюс. 2013. (Nikonenko AG. Introduction to quantitative histology. Kyiv: Kniga-Plus. 2013).

15. Никишин ДВ. Морфология и методы исследования щитовидной железы: методические рекомендации. Пенза: Инф.-изд. центр ПГУ. 2008. (Nikishin DV. Morphology and methods of thyroid research: methodical recommendations. Penza: Inf. of publ. center PGU. 2008)

16. Yanko RV. Investigation of the influence of magnesium ions on the morphofunctional state of the thyroid gland of adult rats. Endokrynologia. 2018;23(3):230-34.

17. Ludwig KS. Structure of the thyroid gland; I. Structure of connective tissue. Acta Anat (Basel). 1952;15(3):300-8.

18. Arem R. The thyroid solution diet. New-York: Atria books. 2012

(Надійшла до редакції 06.02.2019р.)

\section{Влияние метионина на морфологические изменения щитовидной железы крыс}

\section{Р.В. Янко}

Институт физиологии им. А.А. Богомольца НАН Украины

Резюме. Цель - исследовать влияние серосодержащей аминокислоты метионина на морфологические изменения щитовидной железы взрослых крыс. Материал и методы. Исследование проведено на 24 крысах-самцах линии Wistar в возрасте 15 месяцев. Подопытные крысы в дополнение к стандартному рациону ежедневно перорально получали метионин в дозе 250 мг/кг массы тела. Продолжительность эксперимента составила 21 сутки. Из ткани щитовидной железы готовили гистологические препараты по стандартной методике. Морфометрию железы осуществляли на цифровых изображениях с помощью компьютерной программы Image J. Результаты. 21-суточное введение метионина взрослым крысам привело к увеличению относительной площади паренхимы железы, уменьшению размеров фолликулов и коллоида, росту фолликулярно-коллоидного индекса и снижению индекса накопления коллоида, увеличению численности резорбированных вакуолей в коллоиде фолликулов, количества интерфолликулярных островков, уменьшению относительной площади стромы в железе

Выводы. Введение метионина (в дозе 250 мг/кг) привело к появлению морфологических признаков роста синтетической активности щитовидной железы. Это может иметь практический интерес в плане использования метионина для повышения функции железы.

Ключевые слова: метионин, щитовидная железа.

\section{The effect of methionine on the morphological changes of the thyroid gland of rats}

\section{R.V. Yanko}

O.O. Bogomoletz Institute of Physiology, Nat. Acad. Sci. of Ukraine

Abstract. Purpose - to investigate the effect of sulfuric amino acid methionine on morphological changes of thyroid gland in adult rats. Material and methods. The study was conducted on 24 male Wistar rats at the age of 15 months. Experimental rats orally received methionine daily at a dose of $250 \mathrm{mg} / \mathrm{kg}$ body weight. Duration of experiment was 21 days. From thyroid tissue preparations were made according to standard histological methods. Gland morphometry was performed on digital images using a computer program Image J. Results. It was revealed that the 21 daily influence of methionine to adult rats increased the relative area parenchyma gland, decrease follicles and colloid sizes, growth follicular-colloidal index and reduce colloid accumulation index, increase the number of resorption vacuoles in the colloid follicles, amount interfollicular islets, decrease the relative area of connective tissue in the gland. Conclusions. Introduction of methionine (at a dose of $250 \mathrm{mg} / \mathrm{kg}$ ) has morphological signs of growth of the thyroid gland synthetic activity. This may have a practical interest in using methionine to enhance the function of the gland.

Keywords: methionine, thyroid gland. 